\title{
Anticonvulsant and Sedative Properties of Leaves of Neoboutonia velutina (Euphorbiaceae) Prain in Mice
}

\author{
Germain Jean Magloire Ketcha Wanda ${ }^{1,}$, , Steve Guemnang Ngitedem $^{2}$, Sefirin Djiogue ${ }^{2}$, \\ Franklin Zemo Gamo², Dieudonne Njamen ${ }^{2}$ \\ ${ }^{1}$ Department of Psychology, Faculty of Arts, Letters and Social Sciences, University of Yaounde I, Yaounde, Cameroon \\ ${ }^{2}$ Department of Animal Biology and Physiology, Faculty of Science, University of Yaounde I, Yaounde, Cameroon
}

Email address:

ketchawanda@yahoo.com (G. J. M. K. Wanda)

\section{To cite this article:}

Germain Jean Magloire Ketcha Wanda, Steve Guemnang Ngitedem, Sefirin Djiogue, Franklin Zemo Gamo, Dieudonne Njamen. Anticonvulsant and Sedative Properties of Leaves of Neoboutonia velutina (Euphorbiaceae) Prain in Mice. Journal of Diseases and Medicinal Plants. Vol. 1, No. 2, 2015, pp. 24-30. doi: 10.11648/j.jdmp.20150102.11

\begin{abstract}
Neoboutonia velutina Prain is a small tree of 6-12 m, found in tropical areas of Africa (Cameroon, Zimbabwe, Malawi, Nigeria, Angola and Southern Sudan). This plant is used in Cameroonian traditional medicine for the treatment of central nervous system diseases like epilepsy and for the treatment of hepatitis. In our knowledge, there are no published studies on biological activity of $N$. velutina. In the present study, in vivo animal models of epilepsy (strychnine, pentylenetetrazol and Picrotoxin-induced convulsions) and insomnia (diazepam -induced sleep) were used to evaluate the anticonvulsant and sedative properties of $N$. velutina. The aqueous extract of the leaves of $N$. velutina protected mice against strychnine $(\mathrm{p}<0.05)$, pentylenetetrazol $(\mathrm{p}<0.01)$, and picrotoxin $(\mathrm{p}<0.001)$-induced seizures. The extract strongly increased the total sleep time induced by diazepam $(50 \mathrm{mg} / \mathrm{kg}$ i.p. $)$ but did not significantly precipitate the onset of sleep. The results lead to the conclusion that the extract of $N$. velutina possesses anticonvulsant and sedative properties in mice and could explain its use in traditional medicine for the treatment of epilepsy and insomnia.
\end{abstract}

Keywords: Neoboutonia velutina, Aqueous Extract, Anticonvulsant, Sedative

\section{Introduction}

Pathologies of the nervous system are known as the most incapacitating diseases. Epilepsy and insomnia are two of them and are very widespread in the world. Epilepsy is characterised by the repetition of crisis which result from the excessive activity of neurons in brain [1]. According to the WHO (World Health Organisation) report figure of 2013 [2], about 50 million of persons in the world suffer of epilepsy. In Cameroon, his prevalence was about $5.8 \%$ in 2002 [3]. Insomnia is a neuropsychiatric disease characterized by the deterioration of the quality and/or sleeping time. It affects approximately $9 \%$ to $12 \%$ of the world population [4]. Modern treatments for these diseases are mostly based on the use of anti-epileptics and sleeping tablets. These drugs are efficient but present many side-effects such as dependence, drowsiness, nausea etc. Therefore, phytotherapy is an alternative to the modern treatments and plays an important role in the management of diseases mainly among peoples with very low incomes [5]. Over 300,000 plants species known in the world grow in tropical areas of Africa and other continents. About 5000 species of these plants are used for centuries in traditional medicine to prevent and treat diseases [6]. Ethnobotanical enquiries have revealed that the infusion of leaves of $N$. velutina is used to treat epilepsy. The present study explores the anticonvulsant property of $N$. velutina by investigating its suppression of seizures induced by chemicals, pentylenetetrazol, strychnine and picrotoxin which enhance excitatory responses in the central nervous system by inhibiting inhibitory responses to glycine and gamma amino butyric acid respectively [7]. We also evaluated the sedative properties of $N$. velutina using in vivo mice models of insomnia.

\section{Material and Methods}

\subsection{Animals}

Adult male and female mice Mus musculus Swiss weighing 20-26 g between 8 and 12 weeks old were used for this study. The animals were housed in an environmentally controlled room (temperature $25^{\circ} \mathrm{C}$; humidity 50-80\%; 12 
hours light-dark cycle). They were provided tap water ad libitum and fed with a standard mice diet. The study was conducted in accordance with nationally and internationally accepted principles for laboratory animal use and care.

\subsection{Plant Material}

$N$. velutina Prain (Euphorbiaceae) grows in Africa precisely in Malawi, Mozambique, Zambia, Nigeria, Angola, Southern Sudan, Cameroon etc. It is a medium to large tree which can grow up to 6-12 $\mathrm{m}$ in height, and can be found in forest margins and woodland, usually in swampy ground beside streams, also in evergreen swamps forest. The plant specimen of $N$. velutina used was collected in Mbouda in the western region of Cameroon. A voucher specimen of the plant were authenticated $\left(\mathrm{N}^{\circ} 51811 / \mathrm{NHC}\right)$ at the National Herbarium of Cameroun.

\subsection{Chemicals}

Diazepam and Clonazépam were purchased from Roche (Fontenay-sous-bois, France). Strychnine (STR) nitrate, Pentylenetetrazol (PTZ) and Picrotoxin (PIC) were obtained from Sigma Chemical, (Saint louis, USA)

\subsection{Preparation of the Aqueous Extract}

The aqueous extract was prepared following the recommendations of the traditional healer. Dried leaves of $N$. velutina were ground. $600 \mathrm{~g}$ of the obtained powder were infused in $10 \mathrm{~L}$ boiled water for 1 hour. After cooling, the mixture was filtered with a Watman No4 filter paper and the filtrate lyophilized resulting to $58 \mathrm{~g}$ dried extract representing a $9.66 \%$ yield.

\subsection{Animal Experiments}

For the anticonvulsant tests, the animals were randomly divided into five groups of five animals each except for the diazepam-induced sleep test, where four groups were used. As negative control, one group received vehicle (distilled water), another one, the positive control group, was given clonazepam as a reference, and three test groups received different doses of the plant extract. The aqueous extract was administrated (given) per os at the doses of 14; 77 and 140 $\mathrm{mg} / \mathrm{kg}$ body weight (BW) respectively. Clonazepam, Diazepam, Strychnine nitrate, Pentylenetetrazol and Picrotoxin were administrated intraperitoneally in a volume of $10 \mathrm{ml} / \mathrm{kg} \mathrm{BW}$. The study was conducted in accordance with nationally and internationally accepted principles for laboratory animal use and care.

\subsubsection{Strychnine (STR) Test}

Convulsions followed by death were induced in male mice by the i.p. injection of $2.5 \mathrm{mg} / \mathrm{kg}$ STR nitrate. Different treatments were given 1 hour before STR injection. Animals which survived more than 10 minutes after the injection of strychnine were qualified protected. The positive control group received $3 \mathrm{mg} / \mathrm{kg}$ BW clonazepam [8].

\subsubsection{Pentylenetetrazol (PTZ) Test}

Clonic seizures were induced in male mice by i.p. injection of $70 \mathrm{mg} / \mathrm{kg} \mathrm{BW}$ PTZ [9]. The protective effect of $N$. velutina was recorded in mice treated 1 hour after the aqueous extract. The positive control group received i.p. $0.1 \mathrm{mg} / \mathrm{kg} \mathrm{BW}$ of clonazepam. Animals were then individually placed in trays and observed immediately after injection of PTZ for a period of 10 minutes. The latency and duration of seizures were recorded [10].

\subsubsection{Picrotoxin (PIC) Test}

Seizures were induced in male mice by i.p. injection of 7.5 $\mathrm{mg} / \mathrm{kg}$ BW PIC [8] 1 hour after different treatments. A protective effect of the aqueous extract against picrotoxininduced seizures was recorded. The animals which did not convulse after 15 minutes of observation were qualified protected. The positive control received $0.4 \mathrm{mg} / \mathrm{kg} \mathrm{BW}$ of clonazepam.

\subsubsection{Diazepam-Induced Sleep in Mice}

A well described method was used [11]. Mice were divided into four groups of five animals each: one negative control group received vehicle and three groups treated with three doses $(14,77$ and $140 \mathrm{mg} / \mathrm{kg} \mathrm{BW})$ of $N$. velutina extract. The latency of onset of sleep and the sleeping time was recorded. The sleep-potentiating effects of plant extract were studied in mice that received diazepam, $50 \mathrm{mg} / \mathrm{kg} \mathrm{BW}$, and 1 $\mathrm{h}$ after the administration of the extract or distilled water. The time between the loss of the straightening reflex and its recovery was taken as sleep time. The straightening reflex (defined as the movement of the forehand which is on the same side of the stimulated ear) was elicited on a wake mice by stimulating the external ear with feather of a bird.

\subsection{Statistical Analysis}

The fisher exact (two tail) was used to compare percentage of protected mice in each anticonvulsant test. For the latency of onset of sleep and sleeping time, the mean values of the control group were compared with the mean value of the groups treated with the extract using analysis of variance (one way-ANOVA) followed by Dunnett's test. A value of $\mathrm{p}<0.05$ was considered significant.

\section{Results}

\subsection{Effect of $N$. velutina on Strychnine-Induced Seizures}

Strychnine induced seizures and death of all mice in the negative control group. Clonazepam completely protected mice against STR-induced seizures while the aqueous extract of $N$. velutina at the dose of $77 \mathrm{mg} / \mathrm{kg} \mathrm{BW}$, protected $60 \%$ of mice against STR-induced seizures $(\mathrm{p}<0.05)$ (figure 1$)$. 

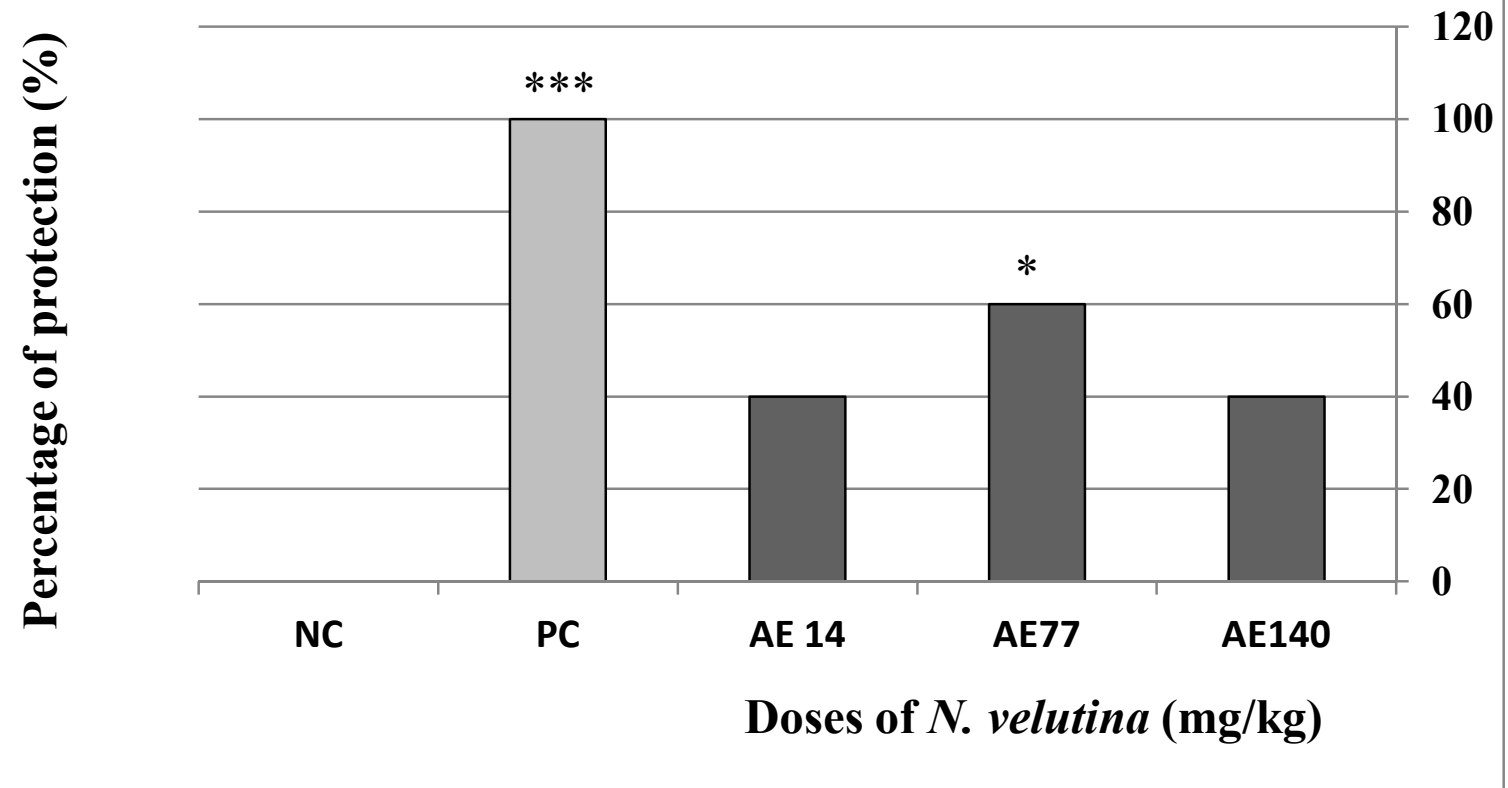

Figure 1. Effect of N. velutina on strychnine-induced seizures in mice. Histograms represent the percentages of protected animals. Each group consisted of 5 animals. *indicates a significant difference as compared to the vehicle-treated animals using Fisher's exact test; ${ }^{*} p<0.05, *_{* *} p<0.001, N C$, negative control: distilled water. PC, positive control: clonazepam $0.3 \mathrm{mg} / \mathrm{kg}$. AE, aqueous extract.

\subsection{Effect of N. velutina on Pentylènetétrazol -Induced Seizures}

Compared to Clonazepam which completely protected mice against PTZ-induced seizures ( $\mathrm{p}<0.001)$, two doses $(77$ and $140 \mathrm{mg} / \mathrm{kg} \mathrm{BW}$ ) of the aqueous extract of $N$. velutina induced $80 \%$ of protection of mice against PTZ-induced seizures $(\mathrm{p}<0.01)$ (figure 2$)$.

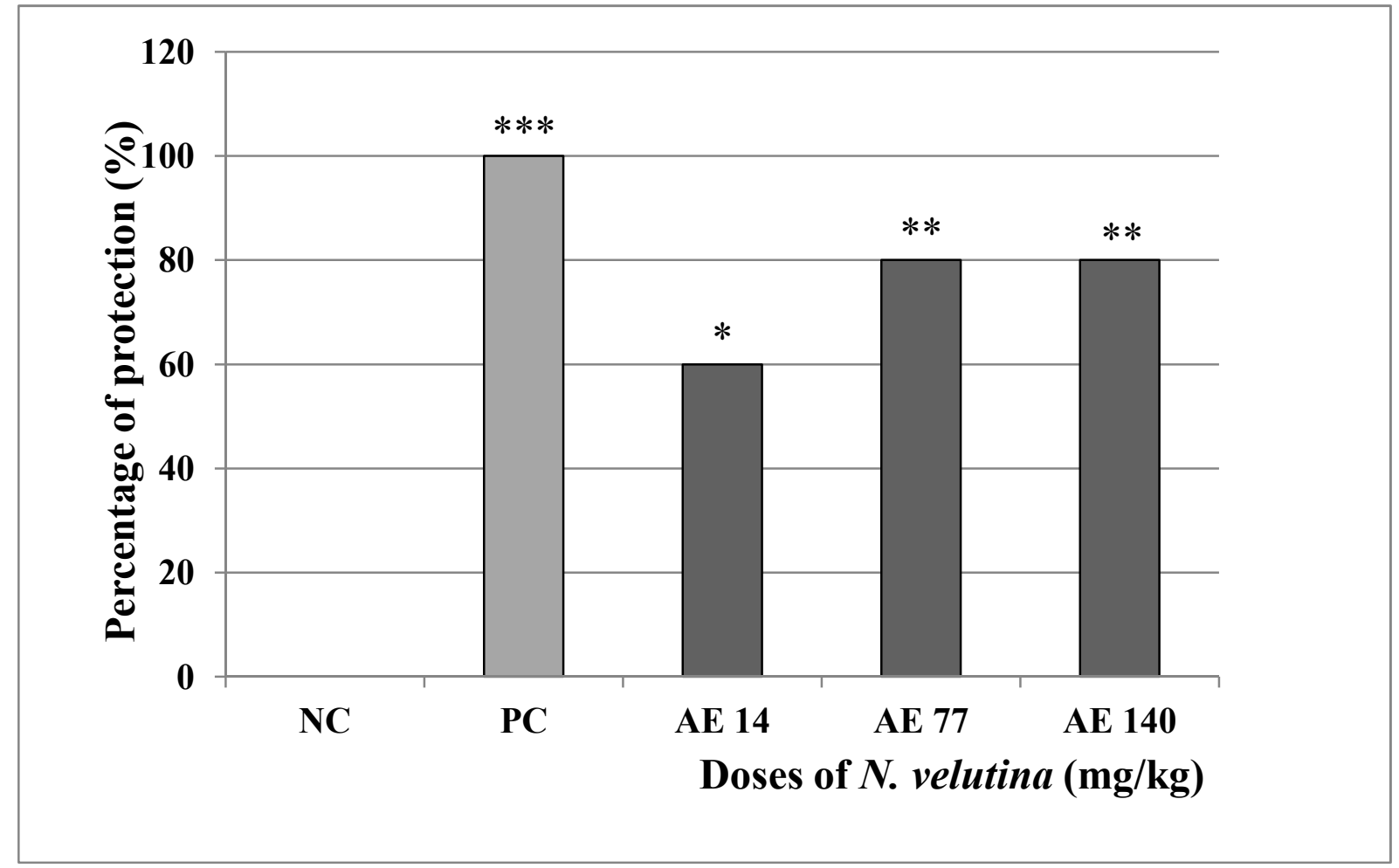

Figure 2. Effect of N. velutina on pentylenetetrazol-induced seizures in mice. Histograms represent the percentages of protected animals. Each group consisted of 5 animals. *indicates a significant difference as compared to the vehicle-treated animals using Fisher's exact test ${ }^{*} p<0.05, * * * p<0.001, N C$, negative control: distilled water. $P C$, positive control: clonazepam $0.1 \mathrm{mg} / \mathrm{kg}$. AE, aqueous extract. 


\subsection{Effect of N. velutina on Picrotoxin-Induced Seizures}

$N$. velutina's extract significantly protected mice against PIC-induced seizures at all the tested doses $(14 \mathrm{mg} / \mathrm{kg} \mathrm{BW}$ $(\mathrm{p}<0.001), 77$ and $140 \mathrm{mg} / \mathrm{kg} \mathrm{BW}(\mathrm{p}<0.01)$. As expected, Clonazepam completely protected mice against PIC induced seizures (Figure 3).

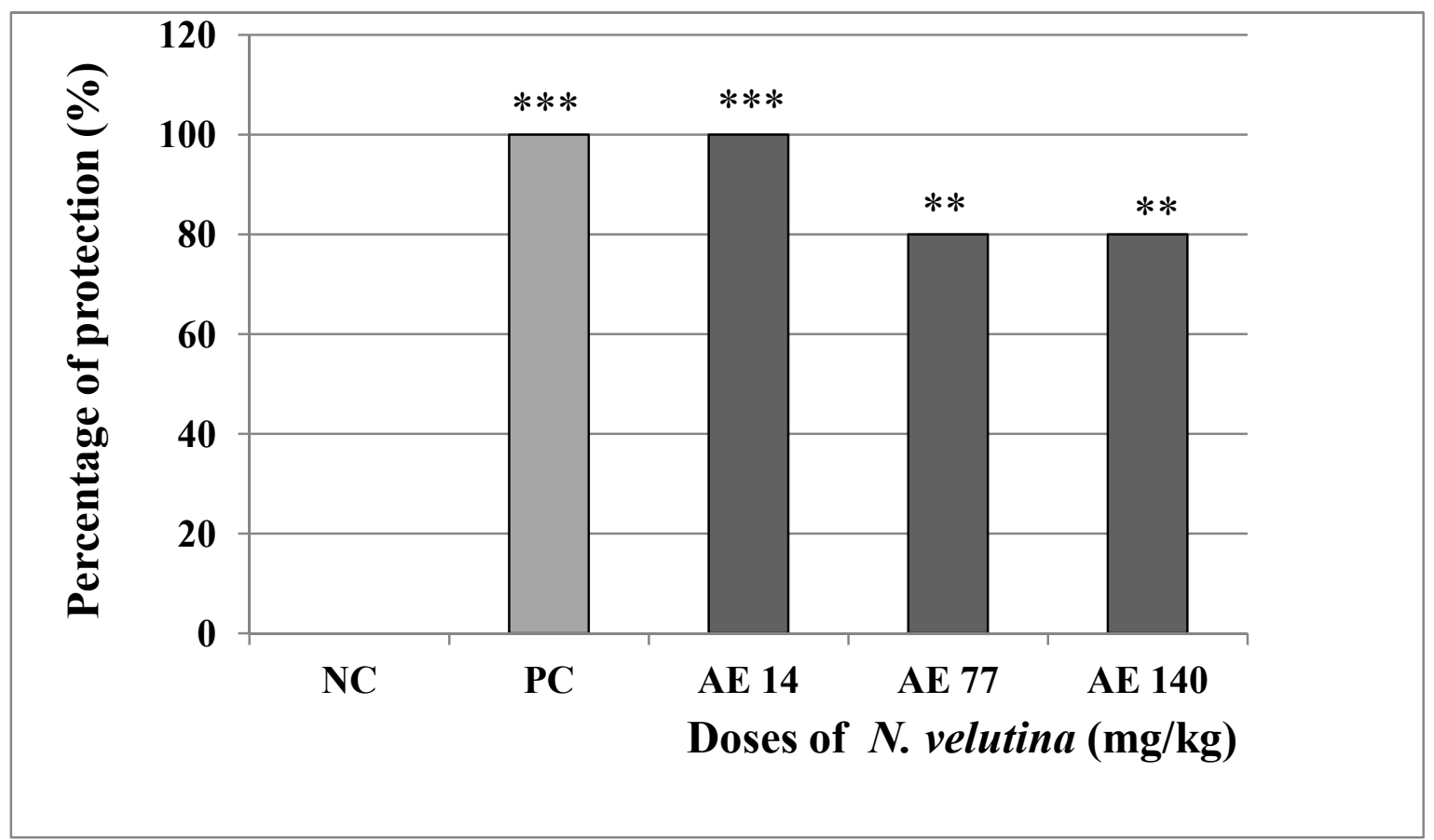

Figure 3. Effects of $N$. velutina on picrotoxin-induced seizures in mice. Histograms represent the percentages of protected animals. Each group consisted of 5 animals. *indicates a significant difference as compared to the vehicle-treated animals using Fisher's exact test; ${ }^{*} p<0.05,{ }^{* * *} p<0.001$. NC, negative control: distilled water. PC, positive control: clonazepam $0.04 \mathrm{mg} / \mathrm{kg}$. AE, Aqueous Extract.

\subsection{Effect of $N$. velutina on the Latency of Onset of Sleep}

The aqueous extract of $N$. velutina has no significant effect on the latency of onset on sleep at all the tested doses (Figure $4)$.

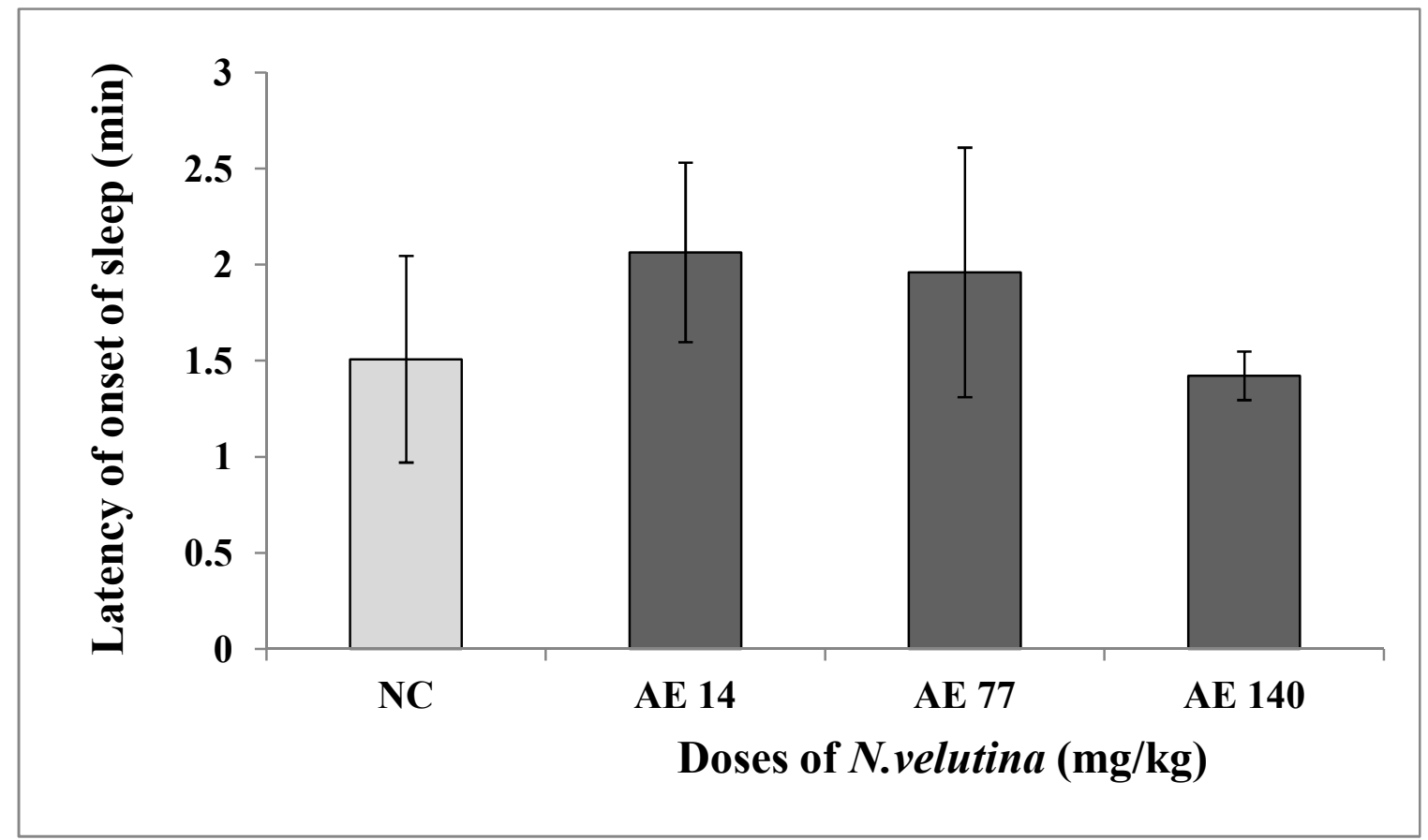

Figure 4. Effects of N. velutina on diazepam-induced sleep. Histograms show latency of onset of sleep induced by diazepam in the presence of doses of the extract in mice. Each group consisted of 5 animals. Data represent means \pm SEM. * indicates a significant difference as compared to the vehicle-treated animals (one-way ANOVA followed by Dunnett's test). NC, negative control: distilled water, AE, aqueous extract. 


\subsection{Effect on N. velutina on Total Sleep Time}

The extract of $N$. velutina strongly potentiated $(\mathrm{p}<0.01 ; \mathrm{p}$ $<0.001)$ the sleeping time induced by diazepam $(50 \mathrm{mg} / \mathrm{kg}$ $\mathrm{BW}$ ): from $55.25 \pm 8.25 \mathrm{~min}$ in the control group to $90 \pm$
$15.1 \mathrm{~min}$ and to $144.66 \pm 20.43 \mathrm{~min}$ in the groups treated with the doses $77 \mathrm{mg} / \mathrm{kg}$ and $140 \mathrm{mg} / \mathrm{kg}$ of the extract respectively (Figure 5).

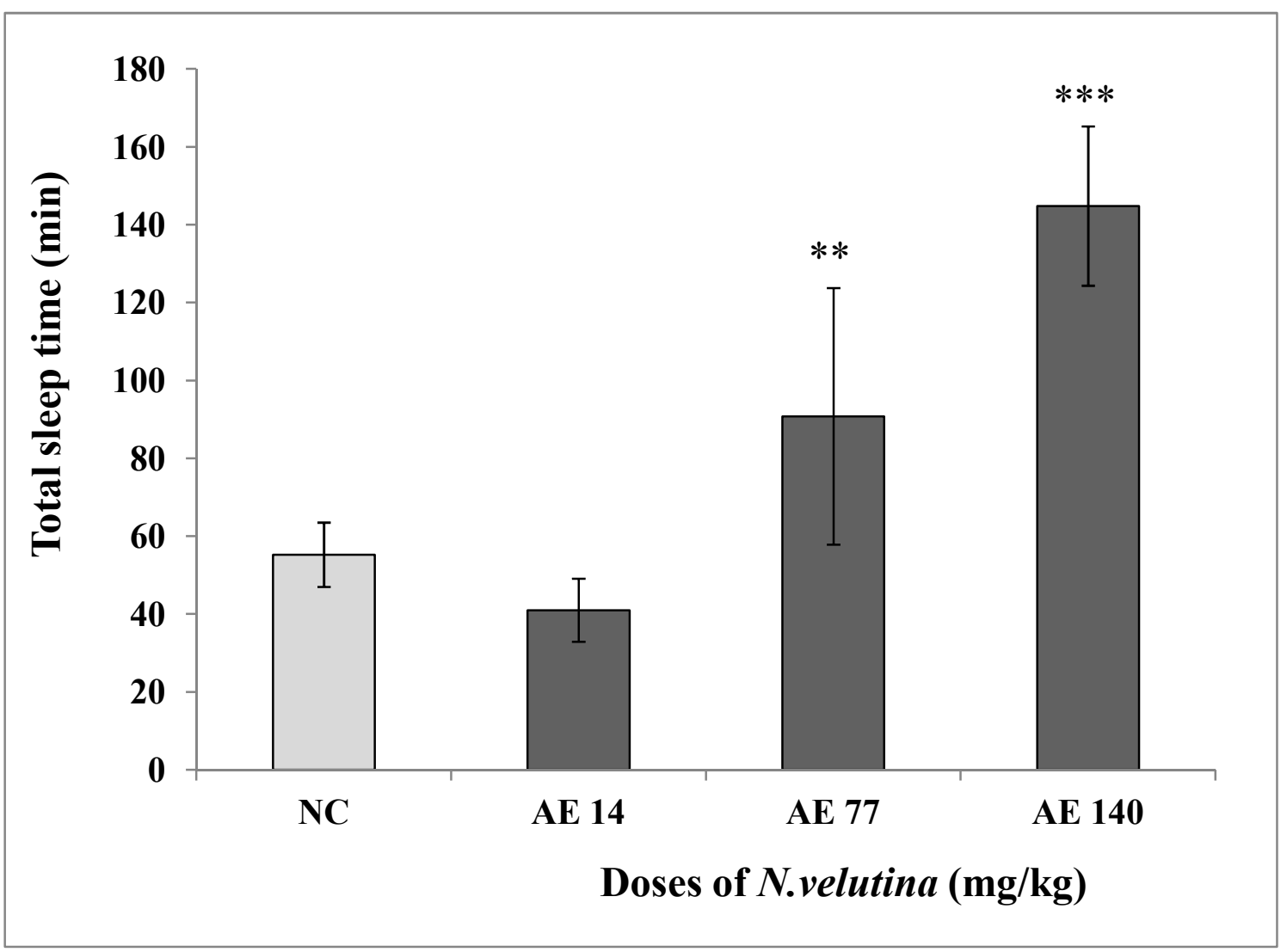

Figure 5. effects of $N$. velutina on diazepam-induced sleep in mice. Histograms represent the total sleep time (min) induced by diazepam in the presence of the extract in mice. Data represent means \pm SEM. $*$ indicates a significant difference as compared to the vehicle-treated animals; $* * p<0.01, * * * p<0.001$ (one-way ANOVA followed by Dunnett's test). NC, negative control: distilled water; AE, aqueous extract.

\section{Discussion}

Epileptic seizures arise from an excessive synchronous and sustained discharge of a group of neurons due to the alterations of synaptic transmission and/or intrinsic properties of neurons [12]. It could also be related to imbalance between elements that excite and those which depress the nervous system. In any case, anti-epileptic drugs (AEDs) could be able to reestablish the equilibrium. The aqueous extract of $N$. velutina $(77 \mathrm{mg} / \mathrm{kg} \mathrm{BW})$ showed anticonvulsant effects in the strychnine induced seizure model. The aqueous extract also antagonized the seizures induced by pentylenetetrazol and picrotoxin. These observations suggest that the extract has considerable glycinergic and GABAergic potentiating mechanisms. Glycine and gamma amino butyric acid (GABA) are amino acids which act as inhibitory neurotransmitters in the central nervous system, the inhibition of which has been implicated in convulsions. Strychnine, a toxic alkaloid causes hyper-excitability and hyper-reactivity of neuron by his fixation on glycine receptors. It is a potent spinal cord convulsant that blocks glycine receptors selectively to induce excitatory response in the central nervous system. The inhibition by the aqueous extract of STR-induced seizures suggests the presence of anticonvulsant properties $[13,14]$ and the involvement of glycine receptors [15].This antagonism could be attributed to bioactive compounds present in the extract, capable to hinder the fixation or thwart the effect of STR as suggested by Ngo Bum et al. [8] in the study of anticonvulsant properties of Senna spectabilis.

The antagonism of pentylenetetrazol and picrotoxininduced seizures suggests the interaction of the extract of $N$. velutina with GABA-ergic neurotransmission and contradicts the assertion that most drugs with an anticonvulsant activity do not counteract pentylenetetrazol seizures, but only retard them [16]. Pentylenetetrazol and picrotoxin both influence the GABA-ergic transmission by hindering the opening of the chlorine channels associated to GABA receptors $[17,18]$. It is known that PTZ test is designed to identify anticonvulsant drugs effectives against generalized clonic seizures $[19,20]$. This is why it can be suggested that $N$. velutina possesses anticonvulsant efficacy against the above 
mentioned seizures type in mice. Picrotoxine blocks GABA $_{A}$ receptors and is widely used as a model of chemicallyinduced convulsion and produces a generalized clonic-tonic seizure [21]. The antagonism of PIC-induced seizures obtained in our study, confirmed the anticonvulsant effect of the aqueous extract of $N$. velutina. This corroborates the results of Karunakar et al. [22] who observed an inhibition by extracts of Carissa carandas of seizures elicited by pentylenetetrazol and picrotoxin in mice, and suggested that the obtained effects might be due to the activation of the GABA transmission precisely by opening the chorine channel associated to GABA receptors. The anticonvulsant action of the extract was probably due to its inhibition of the effects of strychnine and picrotoxin at glycine and $\mathrm{GABA}_{\mathrm{A}}$ receptor sites respectively.

The aqueous extract of $N$. velutina has not precipitated the onset of sleep but significantly increase the total sleep time. This result suggests that the extract possess sedative effects $[23,24]$. The sedative properties of $N$. velutina could be related to the presence of compounds in the extract activating the benzodiazepine and/or GABA sites in the GABA receptor complex [25]. Tannins could be those active components of $N$. velutina as they are known to possess anticonvulsant and sedatives properties [26].

In conclusion, this study suggests that $N$. velutina possess anticonvulsant and sedative properties. These properties could explain the use of this plant in traditional medicine in Africa, particularly in Cameroon in the treatment of epilepsy and insomnia.

\section{Acknowledgement}

We are very thankful to NGUELEFACK Télesphore B. of the University of Dschang for having provided the chemical material, to Calvin TAMDJO and DJOKO Michel Desvariaux of the University of Yaoundé I for their support during the experimentations.

\section{References}

[1] Engel J., Timothy J.R.A., Pedley., Aicardi J., Dichler A.M., Heinemann U., Moshé S., Porter J.R., Taylor D.C., 1997. Epilepsy: a comprehensive textbook. Lippicot Roven Publisher. 500 p.

[2] WHO., 2013. Aide-mémoire $\mathrm{N}^{\circ} 165$. Epilepsie: étiologie, épidémiologie et pronostic.

[3] Njamshi A., Dongmo L., Simi V., Echoufo B., Pepouoni M.N., Kamndem P., Atchou G., 2002. Epilepsy in rural Cameroun: the alarming prevalence rates in the Mbam valley. $169^{\text {th }}$ conference of the swiss society of neurology in Zoug. pp. 2325 .

[4] Taylor D. J., Lichstein K.L., Durrence H., Reidel B. W., Bush A. J., 2005. Epidemiology of Insomnia, Depression, and Anxiety. SLEEP, Vol. 28, No. 11.

[5] Adjanohoun E. J., 1988. Contribution aux études ethnobotaniques et floristiques en République populaire du
Congo. ACCT, Paris, pp : 605.

[6] Iwu M. M., 1993. Handbook of African medicinal plants. CRC Press. Boca Raton fl., ISBN-10: 084934266X.

[7] Purves, Dale, Augustine, G.J., Fitzpatrick, D., Hall, W.C., LaMantia, A., McNamara, J.O., White, L.E., 2008. Neuroscience, 4th ed. Sinauer Associates, pp. 137-138.

[8] Ngo Bum E., Nkantchoua G.N., Njikam N., Taiwe G.S., Ngoupaye G.T., 2010. Anticonvulsant and sedative activity of leaves of senna spectabilis in mice. International j. pharmacol. 6(2): 123-128.

[9] Ngo Bum E., Taiwe S.G., Moto O.F., Ngoupaye T.G., Nkontchoua N.C.G., 2009a. Anticonvulsant, anxiolytic and sedative properties of roots of Nauclea latifolia Smith in mice. Epilepsy behav. 15: 434-440.

[10] Hema B., Bhupendra S., Mohamed Saleem T.S., Gauthaman K., 2009. Anticonvulsant Effect of Drosera burmannii Vahl. Int. J. Appl. Res.Nat. 2(3): 1-4.

[11] Rakotonirina S. V., Ngo Bum E., Rakotonirina A., Bopelet M., 2001. Sedative properties of the extract of the rhizome of Cyperus articulatus. Fitoterapia 72: 22-29.

[12] Engelborghs S., D’Hooge R., De Deyn P. P., 2000. Pathophysiology of epilepsy. Review article. Acta neurol.belg. 100: 201-213.

[13] Trailovic S. M., and Varagic V. M., 2007. The effect of invermectin on convulsions in rats produced by lidocaine and strychnine. Vet. Res. Commun. 31: 863-872.

[14] Park H. G., Yoon S. Y., Choi J. Y., Lee G. S., Choi J. H., et al., 2007. Anticonvulsant effect of Wogonin isolated from Scutellaria baicalensis. Eur. J. Pharmacol. 574: 112-119.

[15] Findlay, G.S., Wick M. J., Mascia M. P., Wallace D., Millier G. W., Harris R. A., Blednov Blednov Y. A., 2002; Transgénic expression of a mutant glycine receptor decrease alcohol sensitivity of mice. J. Pharmacol. Exp. Ther. 300: 526-534.

[16] Loscher, W., Fassbender C. P., Nolthing B., 1991. The role of technical, biological and pharmacological factors in the laboratory evaluation of anticonvulsant drugs 11. Maximal electroshock seizure models. Epilepsy Res. 8: 79-84.

[17] Rizuj S., Muker D., and Mathur., 1980. A new report of possible source of natural herbicide. Indian J. Exp. Biol. 18:777-778.

[18] Caceres A., Lopez B.R., Giron M.A., Logemann H., 1991. Plants used in Guatemala for the treatment of dermatophytic infections: Screening for antimycotic activity of 44 plant extracts. J. Ethnopharmacol. 31:263-276.

[19] Rogawski M. A., 1992. The NMDA receptor, NMDA antagonists and epilepsy therapy. A status report. Drugs 44: 279-292.

[20] De Deyn P. P., D’Hooge R., Marescau B., Pei Y-Q., 1992. Chemical model of epilepsy with some reference to their applicability in the development of anticonvulsant. Epilepsy Res. 12: 87-110.

[21] Nicoll, R.A., 2007. Introduction to the pharmacology of CNS drugs. In: Katzung, B.G. (Ed.), Basic and Clinical Pharmacology. McGraw-Hill Medical, San Fransisco, pp. 333-346. 
[22] Karunakar H., Shalin P T., Arun B J., Shastry C. S., Chandrashekhar K. S., 2009. Anticonvulsant activity of Carissa carandas Linn. root extract in experimental mice. Trop. J. Pharm. Res. 8 (2): 117-125.

[23] Ngo Bum E., Dawack D. L., Schmutz M., Rakotonirina S.V., Rakotonirina A., 2004a. Anticonvulsant activity of mimosa pudica decoction. Fitotherapia. 75: 310-315.

[24] Ngo Bum E., Ngah E., Ekoundi B. C., Dong C., Ayissi M. R.
E., Rakotonirina S.V., Rakotonirina A., 2004b. The decoction of passiflora edulis possesses sedative and anticonvulsant properties in mice. African j. trad. Complem. Altern. Med. 1: 63-71.

[25] Rang H. P., Dale M. M., Ritter J. M., 1999. Pharmacology, Churchill Livingstone, London, pp: 531.

[26] Bruneton J., 1999. Pharmacognosie, phytochimie des plantes médicinales. Lavoisier, Paris ISBN: 27430003154. 